\title{
FIELD CHARACTERISTICS AND EROSIONAL PROCESSES ASSOCIATED WITH KOMATIITIC LAVAS: IMPLICATIONS FOR FLOW BEHAVIOR
}

\author{
RAY A.F. CAS $\S^{\S}$ AND STEVE W. BERESFORD \\ Department of Earth Sciences, Monash University, Clayton, Victoria, 3168, Australia
}

\begin{abstract}
Although komatiitic lavas have long been depicted as turbulent flows, especially near the vent, field characteristics indicate that many komatiitic lavas did not flow turbulently, or only initially so. The bases of komatiites are commonly conformable with their substrate, including fine pelitic sediments, and the margins of komatiites are overwhelmingly coherent, or marked by local quench-fragmented hyaloclastite breccia. Autobreccias are notably missing. These characteristics are not consistent with turbulent flow, but clearly indicate conditions of laminar flow. If komatiitic flows were turbulent, they should commonly have scoured into substrate sediments through a variety of physical erosion processes, including foundering into underlying seafloor sediments, because of density inversion, and turbulence-induced scouring of sediments. These features are not commonly developed, also indicating that generally komatiites were emplaced under tranquil, laminar-flow conditions. Trough-like structures that commonly host nickel sulfide mineralization have commonly been interpreted to originate by thermal erosion of substrate by the komatiitic lava. The evidence supporting thermal erosion is not strong, and commonly ambiguous. Trough structures at Kambalda, Western Australia, are fault bounded, as noted by several previous investigators. However, there is a common, but not universal, antithetic relationship between trough presence and sediment absence. Removal of sediment from troughs could be explained by physical erosion, with an initial narrow, turbulent flow-head scouring a channel in the underlying sediments. As the lava flows spread laterally, their flow-front velocity decreased, and flow became laminar, so explaining the conformable contacts with substrate and the presence of coherent crusts represented by the random spinifex textural zone. Thermal erosion was rare, and could only have resulted beneath sustained lava tubes, within the flow interior, not from the flow head.
\end{abstract}

Keywords: komatiites, laminar flow, field characteristics, physical erosion.

\section{SOMMAIRE}

Quoique les coulées de lave komatiitique ont maintes fois été considérées turbulentes, surtout près de l'évent, les caractéristiques de terrain indiquent que dans la plupart des cas, le mode d'épanchement n'était pas turbulent, ou s'il l'était, seulement au tout début. La base d'une coulée est en général conforme avec le substrat, y inclus les cas où ce sont des sédiments pélitiques à grains fins qui sont en contact, et les marges sont conformes dans la grande majorité de cas, ou bien localement marquées par une brèche d'hyaloclastite due au refroidissement brutal. Le phénomène d'autobréchification est complètement absent. Ces caractéristiques ne concordent pas avec une hypothèse de turbulence, mais elles indiquent plutôt des conditions d'épanchement laminaire. Si l'épanchement avait été turbulent, la lave aurait creusé dans les sédiments sousjacents selon une variété de mécanismes physiques d'érosion, par exemple affaissement dans les sédiments des fonds marins à cause de l'inversion en densité, et déplacement des sédiments à cause de la turbulence. Ces caractéristiques ne sont pas répandues, de sorte qu'en général, les komatiites semblent avoir été mises en place de façon tranquille, par épanchement laminaire. On interprète généralement les structures en forme d'auge qui contiennent une minéralisation en sulfures de nickel en termes d'une érosion thermale du substrat par la lave komatiitique. L'évidence en faveur d'une érosion thermale n'est pas convaincante, et dans plusieurs cas, ambigüe. A Kambalda, en Australie occidentale, les structures en auge sont limitées par des failles, comme l'ont souligné plusieurs. Il y a toutefois une relation antithétique commune, mais non universelle, entre structure en auge et absence de sédiments. L'élimination de sédiments d'une telle structure pourrait s'expliquer par une érosion physique, avec au début une percée étroite et turbulente créant un chenal dans les sédiments soujacents. A mesure que la coulée s'étendrait latéralement, sa vélocité au front de la coulée irait en diminuant, et le mode d'épanchement deviendrait plutôt laminaire, expliquant ainsi les contacts conformes avec le substrat et la présence de croûtes cohérentes que représente la zone texturale à spinifex aléatoire. L'érosion thermale aurait été rare, et n'aurait pu se développer qu'en dessous des tubes d'épanchement maintenus à l'intérieur d'une coulée, plutôt qu'au front d'une coulée.

(Traduit par la Rédaction)

Mots-clés: komatiites, épanchement laminaire, caractéristiques de terrain, érosion physique.

§ E-mail address: rcas@mail.earth.monash.edu.au 


\section{INTRODUCTION}

Archean komatiitic lavas have long been depicted as dynamic, turbulent flows. However, because no eruption of komatiite has been witnessed, the eruption style and the nature of the vent systems are unknown, and flow behavior is inferred. Concepts of komatiitic lava behavior are based mostly on numerical modeling involving assumptions of high rates of magma discharge, calculated low viscosities and high near-vent flow velocities (Huppert et al. 1984, Huppert \& Sparks 1985, Williams et al. 1998).

Turbulent flow, thermal erosion and assimilation of substrate, producing trough-like structures that commonly contain nickel sulfide mineralization, have become inextricably linked concepts (e.g., Arndt \& Nisbet 1982, Nisbet 1982, Huppert et al. 1984, Lesher et al. 1984, Huppert \& Sparks 1985, Lesher \& Groves 1986, Evans et al. 1988, Hill et al. 1995, Lesher \& Arndt 1995, Perring et al. 1995). In the type area for komatiite-hosted Ni-sulfide ore deposits, the $2.7 \mathrm{Ga}$ (Claoue-Long et al. 1988) komatiite succession at Kambalda, Western Australia, massive ore is commonly located in trough structures at the base of the lowermost komatiite flow (Gresham \& Loftus-Hills 1981). Although thermal erosion has been the most common explanation for the troughs, there have been many different interpretations. The interpretation of troughs is especially complicated by the structural nature of their margins. Deformed contact relationships between komatiites and adjacent units raise a major problem in understanding original contacts, because many of the major komatiite belts in the world occur in polyphase-deformed terranes (e.g., Kambalda, Western Australia: Cowden \& Roberts 1990; Abitibi Belt, Ontario and Quebec: Jackson \& Fyon 1991; the Raglan Horizon, Cape Smith Belt, Quebec: St-Onge \& Lucas 1994).

If komatiitic lava flows were turbulent, why are most komatiite boundaries conformable and coherent? From their high $\mathrm{MgO}$ contents and high temperatures, komatiitic magma is inferred to have had a very low viscosity. How then could it have formed units tens and some even hundreds of meters thick? Also, a low viscosity does not guarantee that komatiites behaved as turbulent flow systems. Given that komatiites formed from dense liquids flowing over low-density water-saturated sediments, many komatiite lava flows should have burrowed or invaded into sediments. How can these features be distinguished? Many unanswered questions exist about the flow behavior and the mode of emplacement of komatiites.

In this paper, we consider the all important field characteristics and geological relationships of komatiites as a means of constraining the physical process of emplacement of komatiitic lava flows, including potential for erosion. Above all, we use principles of uniformitarianism to shed light on the emplacement of komatiitic magmas, which must have been governed by the same physical and chemical principles that apply today.

\section{Characteristics of Komatites}

\section{Composition and physical properties}

Komatiites are ultrabasic igneous rocks with low $\mathrm{SiO}_{2}$ content $(<45 \mathrm{wt} \%)$, high $\mathrm{MgO}$ contents $(>18 \%$ $\mathrm{wt} \%)$, low calculated viscosities at eruption (0.1-10 Pa s), high densities $\left(2.8 \mathrm{~g} \mathrm{~cm}^{-3}\right)$ and high temperatures at eruption $\left(1400-1650^{\circ} \mathrm{C}\right.$ ) (Arndt \& Nisbet 1982 , Huppert et al. 1984, Huppert \& Sparks 1985). Highmagnesium basalts are commonly associated with komatiites, and although they are slightly different compositionally $\left(\mathrm{SiO}_{2}\right.$ in the range $45-52 \mathrm{wt} \%$ : $\mathrm{MgO}$ in the range $10-18 \mathrm{wt} \%$ ), they have many characteristics similar to komatiites, and are considered to have behaved similarly. The viscosity of komatiitic magma was 10 to 100 times lower than that of a basaltic magma, which is commonly considered to be the closest, large-volume natural analogue. Komatiitic magmas were therefore significantly more fluidal than basalts, only 3 to 10 times more viscous than water, and perhaps closely similar to olive oil in viscosity (Williams et al. 1999). Komatiites show a distinct compositional zonation, with the $\mathrm{MgO}$ content increasing sharply from the upper spinifex textural zone to the lower cumulate zone (e.g., Arndt 1986).

\section{Textural zonation and textural asymmetry: distinguishing komatiitic lavas from intrusions}

Komatiite lava flows are characterized by a twotiered textural zonation, consisting of the upper (A) spinifex zone, and lower (B) cumulate zone (Figs. 1, 2; Pyke et al. 1973). There are many variations on this arrangement, which cannot be discussed in detail here. The spinifex zone was originally subdivided by Pyke et al. (1973) into two zones, but Lajoie \& Gélinas (1978), Barnes et al. (1983) and Barnes (1985) recognized a three-fold subdivision. The tops of komatiite flows are commonly marked by a thin aphyric to olivine-phyric, originally glassy interval $\left(A_{1}\right)$ or a random spinifex $\left(A_{2}\right)$ zone of skeletal blades of olivine crystals (or acicular pyroxene crystals in komatiitic basalts and some differentiated komatiites). Both textural zones indicate supercooling (Donaldson 1982, Shore \& Fowler 1999) and are analogous to the chilled surface crust on basalt pillow lavas and subaerial pahoehoe basaltic-type lavas. This upper $\mathrm{A}_{1}-\mathrm{A}_{2}$ interval may be marked by a network of irregularly spaced fractures or, more rarely, a pervasive breccia horizon of clasts of the $A_{1}-A_{2}$ zone. Textures vary from jigsaw fit to clast-rotated (Fig. 3). These breccia textures are only consistent with quench-induced fragmentation resulting from contraction due to supercooling by contact with water, producing hyaloclastite breccias. These breccias are not explosive in origin. 
They are not pyroclastic, as clearly demonstrated by the jigsaw fit of clasts. Explosions would cause the clasts to be widely dispersed, and would not produce in situ frag-

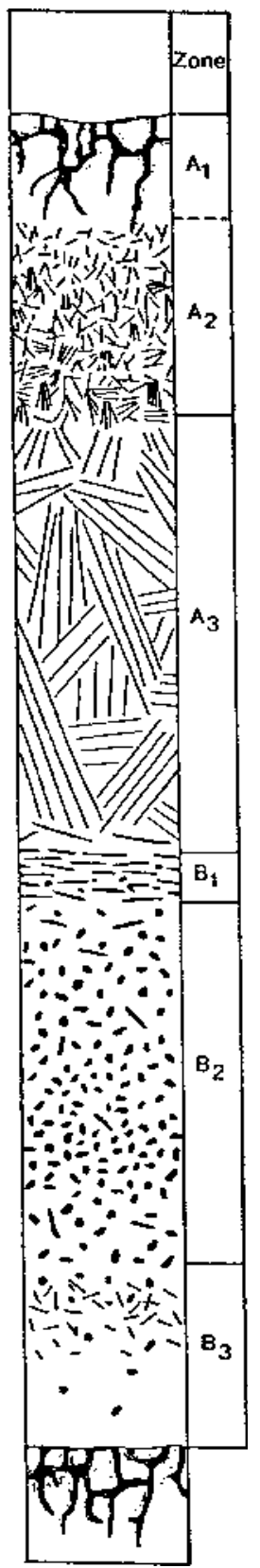

FIG. 1. Two-tiered textural zonation of komatiite lavas into the spinifex A zone and its three subzones, and the underlying cumulate B zone with its three subdivisions (after Arndt et al. 1977). mentation textures. However, some dispersed clast textures in a matrix of sediment occur in peperites and should again not be confused with signs of explosive processes.

Below the $\mathrm{A}_{2}$ zone, and not part of the inferred lava crust, there is commonly a zone of plate spinifex $\left(\mathrm{A}_{3}\right)$, which varies from centimeters to meters in thickness (Fig. 1). Randomly oriented books of parallel-plate spinifex, called random-plate spinifex, to clusters of subvertical, subparallel skeletal plate-like crystals of olivine, called plate spinifex, occur. Plate spinifex is considered to represent very late-stage crystallization under the crust of the lava, from the roof a lava tube in a stagnant residual pool of magma, after flow had ceased (e.g., Arndt 1986).

The B cumulate zone also can be subdivided. The upper $B_{1}$ skeletal hopper crystal zone, which commonly is marked by aligned crystals parallel to the surface of the komatiite, probably also represents a late population of crystals, with flow-induced alignment of crystals occurring under the crust of the lava during the last stages of flow (e.g., Lajoie \& Gélinas 1978). The $\mathrm{B}_{2-3}$ cumulate zone (ortho-, meso-, adcumulate) consists of well-formed equant crystals formed prior to eruption, during flow or after flow had ceased in the interior of the flow. Orthocumulate textures consist of less than $70 \%$ euhedral crystals of olivine dispersed in a glassy or finely crystalline groundmass. In mesocumulate textures, the crystals of olivine (70-90\%) form a mutually touching framework, and the proportion of groundmass is significantly less than in orthocumulate. Ortho- and mesocumulate textures are common in komatiite lavas. Adcumulates consist of greater than $90 \%$ large, mutually interfacing polygonal olivine crystals with little or no groundmass. The base of the B zone, in some cases, grades down into a thin basal fine chilled aphanitic base, resulting from heat loss to the substrate when the lava first moved over the substrate.

An adcumulus texture should generally not be expected in komatiite lavas, except in thick, paleotopographically ponded, lava-lake-like bodies or, more likely, in komatiitic or dunitic intrusions. Coarse textures should be interpreted with care. Modern lavas of any composition do not generate plutonic textures. For example, we do not find gabbroic lavas per se being erupted today; there is no reason why they should have formed in the Archean. However, extremely thick komatiitic lavas may have developed coarse differentiated interiors of gabbroic or pyroxenitic composition. These zones should grade into the normal komatiitic textural zones if the komatiites result from true flows (e.g., Fred's flow, Abitibi: Arndt et al. 1977; Kambalda, our unpublished data).

In addition, komatiites may contain a distinctive pattern of vesicle distribution (Beresford et al. 2000). Vesicles are ubiquitously present in komatiites ( $c f$. Arndt et al. 1998), and have been observed in varying proportions in both thin and thick flows. Thin Munro- 


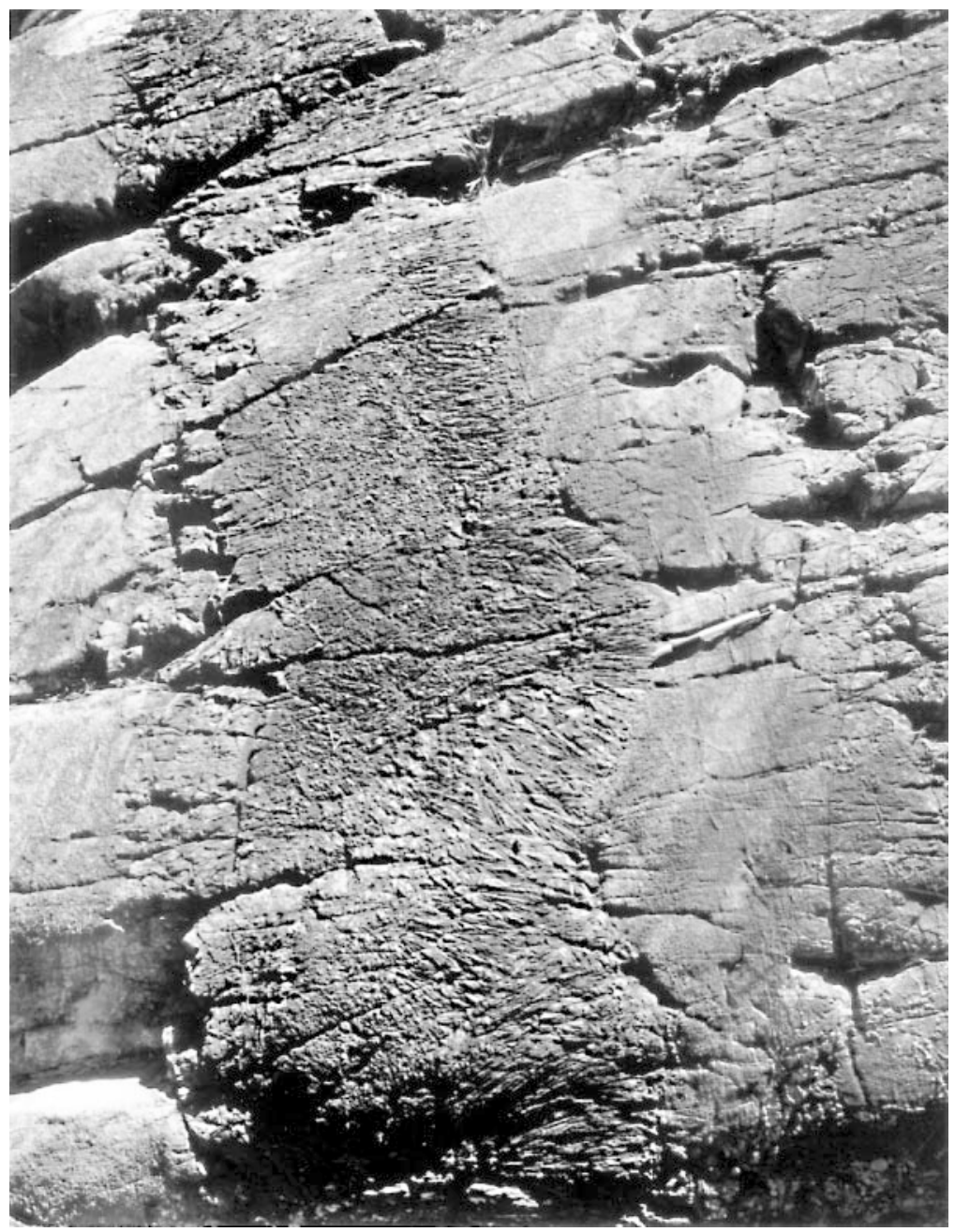

FIG. 2. Spinifex and cumulate textural zones in a thin komatiite lava, Pyke Hill, Abitibi Belt, Ontario, Canada. Note the asymmetry of the textural zonation and the sharp contact between the two zones. Top is to the left.

type flows contain low proportions of vesicles (generally $<3 \%$ ) associated with flow top and spinifex zones (e.g., Barnes et al. 1983). Cumulate zones are commonly vesicle-free. In contrast, spinifex zones in thick Kambalda-type flows are commonly vesicle-poor $(<2 \%)$, whereas vesicle concentrations of up to $30 \%$ have been observed in B zones, in some cases occurring in multiple horizons (Beresford et al. 2000).

Thin Munro-type flows (e.g., Pyke et al. 1973) commonly show a simple textural zonation as outlined above. Thicker Kambalda-type flows may show a more complex multi-tiered textural zonation, with multiple skeletal, cumulate and vesicle horizons (Beresford et al.
2000, Moore et al. 2000), which have implications for processes of emplacement.

Komatiite flows typically have an asymmetrical textural zonation, as summarized above (Figs 1,2). This is a result of asymmetrical cooling and crystallization rates, with rapid cooling occurring from the surface into the ambient aqueous medium, with its high heat capacity (e.g., Shore \& Fowler 1999), and slower loss of heat from the base to the substrate. By contrast, intrusions, especially those into deep-seated country-rock, will have an essentially symmetrical textural zonation because cooling rates around all margins will be similar. Dykes are likely to exhibit textural symmetry, whereas 


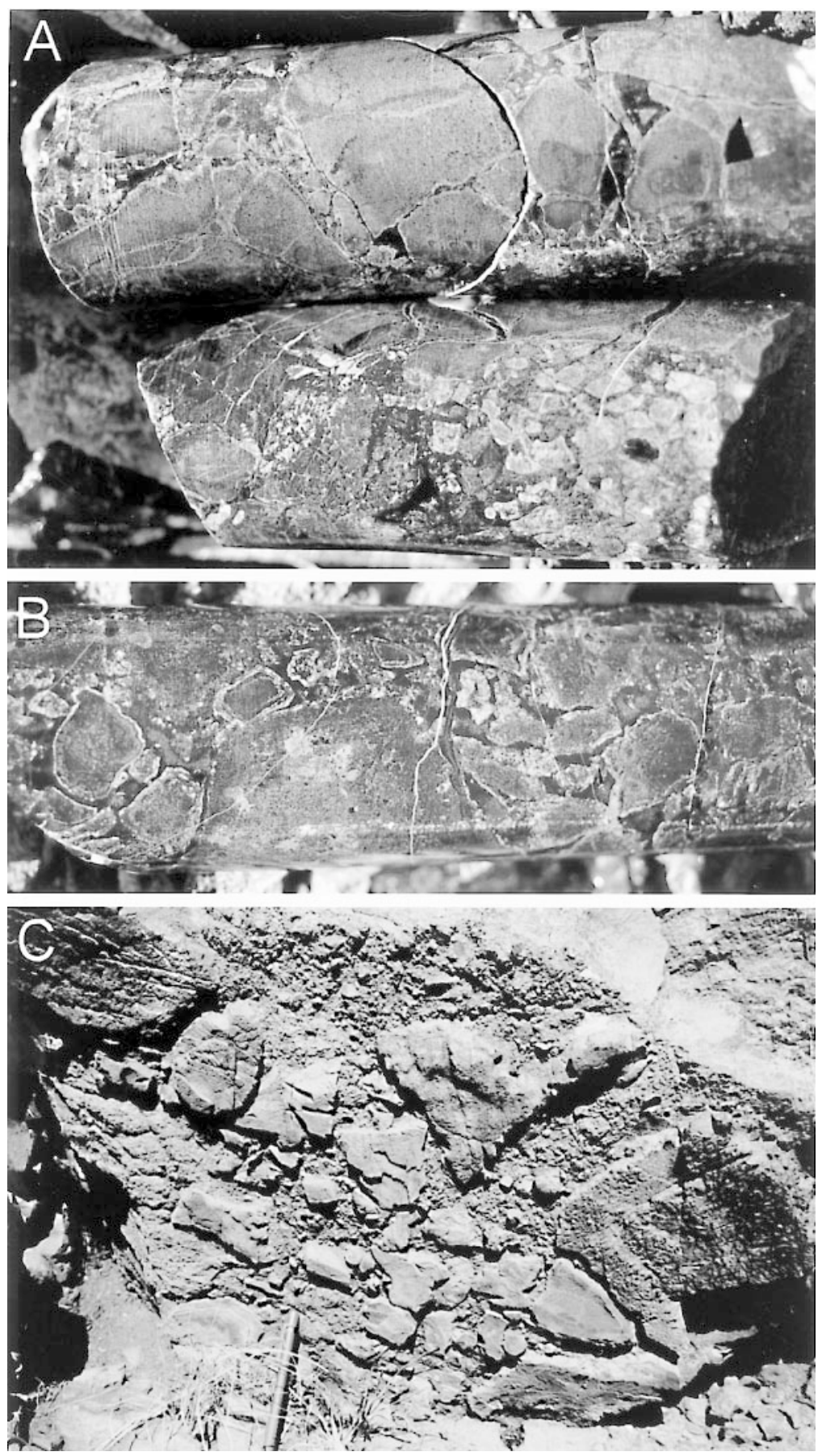

FIG. 3. Flow-top hyaloclastite breccia showing (A) jigsaw-fit texture, and (B) clast-rotated texture, both from diamond-drill hole KD6068, Kambalda, Western Australia. (C) Jigsaw-fit to clast-rotated hyaloclastites from the Barberton Belt, South Africa. 
with sill-like bodies, a slight asymmetry may result from crystal-settling effects. Spinifex-textured zones are less likely in the margins of thick intrusions into country rock because thermal gradients will be lower, but may occur in thin intrusions into country rock or intrusions into unconsolidated sediments. Intruded country-rocks should show evidence of symmetrical contact-metamorphic aureoles or haloes. These should not be confused with later alteration-induced effects along contacts. The geometrical or contact relationships, as discussed below, also can be used to distinguish lavas from intrusions.

\section{Thickness and shape}

Komatiites vary in thickness from centimeters to hundreds of meters. Although Abitibi-type flows tend to be less than $10 \mathrm{~m}$, flows tens of meters or greater are common in other komatiitic provinces. Whether komatiites hundreds of meters thick are lavas is highly questionable because the low viscosity and the hydraulic head in such low-viscosity magmas would generally ensure the formation of thinner lavas (Cas et al. 1999). Although stratigraphic sequences of komatiites have been correlated over long distances (e.g., Hill et al. 1995), no single flow has been traced for more than a few kilometers, and most, for no more than a few tens to hundreds of meters because of poor outcrop and tectonic dismemberment of the terranes in which they occur. It cannot, therefore, be assumed that komatiitic lavas flowed huge distances; some may have, many have not.

Little is known about the three-dimensional shape of komatiitic lavas, because of incomplete exposure. Thick lavas generally appear to be tabular in limited two-dimensional surface outcrop or drill core. But in some cases, difficulty in correlating between drill core as little as 50 to $100 \mathrm{~m}$ apart (e.g., Moore et al. 2000) indicates that the geometry of komatiites can be much more complicated, with significant lateral changes in thickness.

Rare, laterally extensive and continuous outcrops at Spinifex Ridge, Abitibi Belt (Lajoie \& Gélinas 1978), Pyke Hill, Abitibi Belt (Pyke et al. 1973) and Spinifex Stream, Barberton (Dann et al. 1998) preserve multilobate compound flow complexes, which may also provide perspectives on the form of larger, thicker simple flows. Individual lobes are up to $2 \mathrm{~m}$ thick. Some lobes are elongate and cigar-like in shape, with planar parallel upper and lower contacts and tapering, wedging edges (Fig. 4A). Others are laterally more restricted, only a few meters long and have clearly upward convex surfaces, and again wedging, tapering edges (Fig. 4B). The shapes of lobes accommodate the topography of the underlying lobes. In all cases, however, the tops of the lobes are arched above the level at which the taper points at the margins of the lobes lie. The crusts in the centers of the lobes must therefore have been arched up by injection of magma underneath, suggesting that crusts had significant strength, and indicating a feeder-tube mechanism for the transfer of magma from the vent to the flow front.

Similarly instructive exposures occur on islands in Hudson Bay, Canada. Arndt (1982) reported similar morphologies to those summarized above at Gilmour Island, in a succession of komatiitic basalts. Baragar (1984) reported both vertical and lateral transitions from massive to pillowed facies within single komatiitic basalts from the Ottawa Islands and Smith Island. The massive facies zones also had "swollen massive tops" (Baragar 1984, his caption to Fig. 15).

Intrusions will vary in shape depending on the timing and level of emplacement, and the nature of the intruded material. Syndepositional intrusions into water-saturated, unconsolidated sediments generally have highly irregular shapes because the intruded sediment has little mechanical strength, and dense magma is able to push irregularly through the sediments (Beresford \& Cas 2001). Such intrusions will originate where a komatiitic magma rising through the crust encountered a relatively thick succession of low-density, water-saturated, unconsolidated to semiconsolidated sediments on the seafloor. Secondly, where dense komatiitic lava flowed over such sediments on the seafloor, the lava could begin to founder into the sediment, part of it becoming an irregularly shaped invasive flow, as described by Beresford \& Cas (2001).

Intrusions into lithified country-rock can have a variable shape. Small intrusions are more likely to have a tabular shape (e.g., dykes, sills). Larger intrusive bodies are more likely to be irregular in shape. In both cases, contacts could be discordant.

\section{Contact relationships and textures}

The relationship between komatiitic lavas and their substrate varies. In many polydeformed terranes such as Kambalda, the majority of contacts are deformed. However, many are still well enough preserved to allow inferences about original contact relationships. Contacts can be classed into two types: concordant and discordant. Concordant contacts could be conformable stratigraphic contacts, intrusive sill contacts or beddingparallel fault contacts. Discordant or truncated contacts could be original local erosional or more extensive unconformable stratigraphic contacts, cross-cutting intrusive contacts or low- to high-angle fault contacts. Each contact must be assessed on the basis of individual geological contact relationships preserved.

The majority of contacts and the majority of the surface area of the bases of komatiitic lavas at Kambalda show evidence of tectonic strain, but originally appear to have been conformable stratigraphic contacts, with virtually no evidence of erosion of their substrate (Beresford \& Cas 2001). The bases of the komatiites are coherent, the interflow sedimentary horizons have a lateral continuity and a relatively uniform thickness, and 

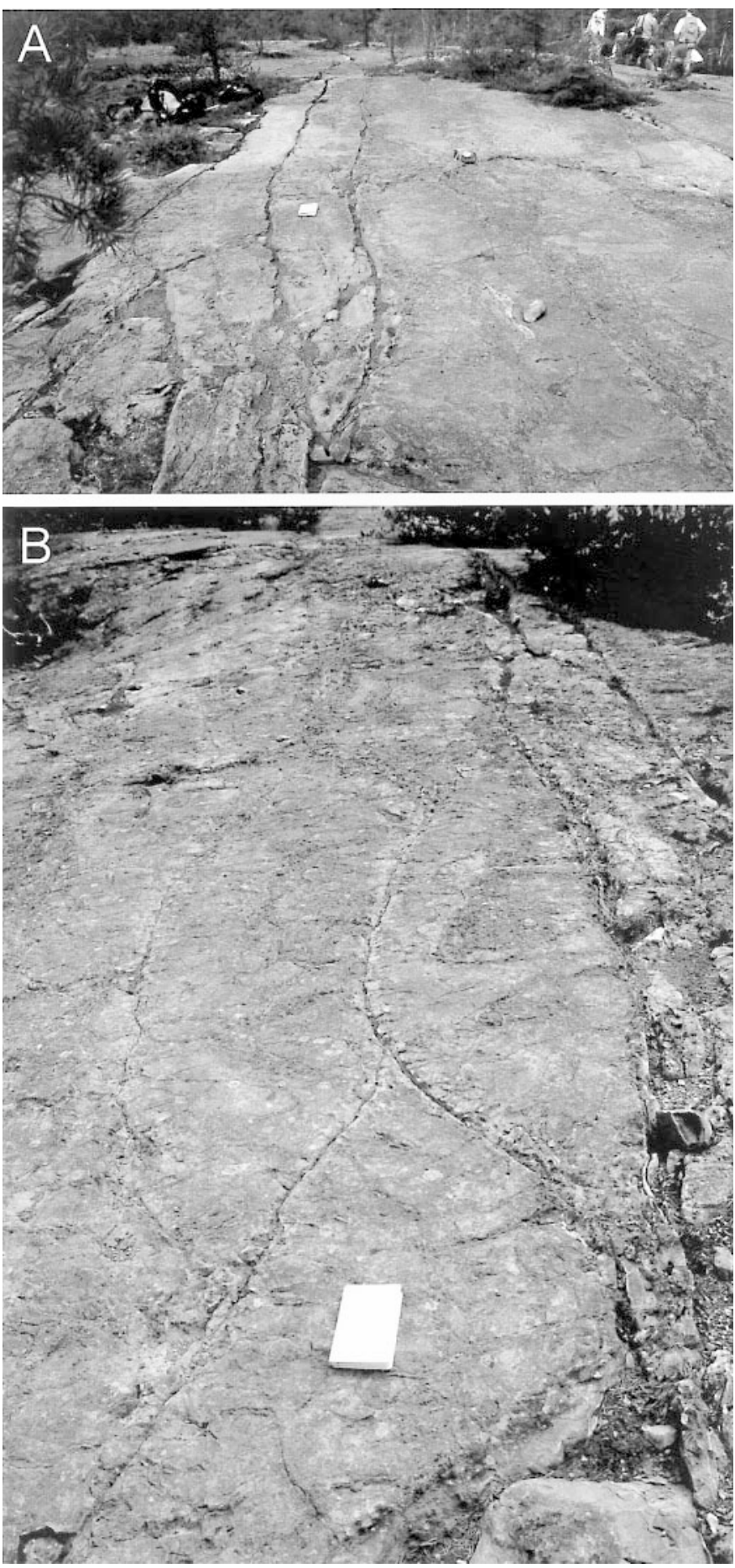

FIG. 4. (A) Elongate lobe of komatiitic lava with wedged, tapering edge and convex-up upper surface; younging to the right. (B) Lensoid lava lobe with well-defined convexup surface; younging to the left. Both photos from Spinifex Ridge, Abitibi Belt, Ontario, Canada. 
the sediments show no sign of soft-sediment disturbance or contact metamorphism.

The trough structures at Kambalda are, however, difficult to interpret. Various origins have been proposed, including (1) original volcanic topographic depressions between non-overlapping lava lobes on the surface of the underlying Lunnon Basalt (Lesher 1983, 1989, Squire et al. 1998), (2) pre- to syn-volcanic faulting (Brown et al. 1999, Evans et al. 1988, Ross \& Hopkins 1975), (3) erupting fissures (Gresham \& Loftus-Hills 1981), (4) thermal erosion channels (Huppert et al. 1984), (5) thermal erosion modified paleotopography (Lesher et al. 1984), (6) post-mineralization faulting (Archibald 1985, Cowden 1988, Cowden \& Archibald 1991, Cowden \& Roberts 1990).

On the basis of experiments involving melting of wax substrates, Huppert \& Sparks (1985) and Jarvis (1995) proposed that thermally eroded channels should have smooth, rounded, embayed, undercut shapes. An embayment of nickel sulfide or komatiite is undercut into the substrate (Fig. 5A) so that there is substrate both below and above komatiite in embayed re-entrants. Troughs at Kambalda have sheared margins, and angular wedge shapes (Figs. 5B, C, D; Cowden \& Roberts 1990, Wolfe 1997, Moore 1998, Moore et al. 2000) and appear to have involved reverse or thrust faulting of the footwall over a basal segment of sulfide or komatiite (or both). Trough structures, however, also occur where there is no massive sulfide. At Wannaway, Widgiemooltha (Wolfe 1997) and McComish, Tramways (Moore 1998, Moore et al. 2000), fault-bound trough structures offset planar contacts, and are associated only with disseminated ore.

However, sedimentary units are absent under many troughs, but not all, whereas adjacent to the troughs ("flank" positions), the bases of the komatiites are relatively planar, conformable and poorly mineralized, and sedimentary horizons are laterally continuous (Fig. 6; Gresham \& Loftus-Hills 1981). Since the sedimentary facies were fine-grained hemipelagic and turbidity-current pelites (Bavinton 1981, Squire et al. 1998, Beresford \& Cas 2001), originally there should have been as much sediment in trough positions as in flank positions. Therefore, in many trough positions, sediment has been removed by erosion to produce channels, whereas in flank positions it has not (Fig. 6). To date, the absence of sedimentary units from the troughs has been assumed to be due to thermal erosion, but we suggest that the cause was more likely physical erosion. In some cases, faulting has been superimposed upon the margins of original erosional volcanic channels (or even lava tubes) to produce structural troughs (Fig. 6). However, not all mineralization nor all troughs coincide with original erosional channels. In places, mineralization formed within the basal parts of komatiites with planar basal contacts (e.g., Cowden 1988). Commonly, faulting has offset planar contacts, also producing trough structures (Cowden \& Roberts 1990, Moore et al. 2000).
We suggest that the term "trough" be reserved for faultbounded troughs, and that the term "channel" be used for original topographic depressions along the bases of komatiites, whether they were pre-existing topographic features, or eroded by the komatiite.

If troughs were of thermal erosion origin, gradational anatectic contacts should be common at the bases of komatiitic lavas. No unequivocal examples have been documented. It is remarkable that where sediment has been eroded and komatiites are in direct contact with the pillow basalts of the Lunnon Basalt, whole pillow margins or plucked out segments occur at the contact (e.g., Fig. 8 in Squire et al. 1998). Sediment has therefore been eroded as though it was swept away, and perhaps pillows or segments have been too, but the evidence for thermal erosion at the contact is absent. Groves et al. (1986) considered interspinifex ore to be indicative of partial melting. Interspinifex ore occurs in the groundmass between spinifex crystals at the top of a lava that underlies the base of a mineralized komatiite in a hanging-wall setting. However, interspinifex ore also occurs isolated within spinifex zones, and below the bases of komatiites that are not mineralized at all (e.g., drill hole KD 8684, at $524 \mathrm{~m}$, Coronet deposit, Kambalda) and, in places, spinifex and equant crystals are replaced by sulfide. We suggest that remobilization of ore and replacement during metamorphism offer more likely explanations for interspinifex ore.

Commonly, the bases of komatiitic lavas are sharp and coherent or fractured, unless overprinted by alteration. Where sedimentary strata underlying komatiitic lavas were unconsolidated at the time of komatiite emplacement, the absence of contact metamorphic effects can be explained in two ways. First, the contacts between sediment particles would have been point contacts, minimizing the amount of conductive transfer of heat. Secondly, water in the pore spaces would have acted as a heat sink. Even solid rock substrate, such as the footwall Lunnon Basalt at Kambalda, does not show evidence of contact metamorphism where in contact with the komatiites, indicating that seafloor rocks may contain enough water in fractures and cavities to absorb the heat of overflowing komatiitic lavas.

Contact metamorphism indicates slow, prolonged loss of heat, and thus intrusive contacts between intrusions and lithified host-rock, which would conduct heat better than unconsolidated sediments. Contact-metamorphosed margins around komatiites do not occur at Kambalda, but have been observed at the margins of some mineralized komatiitic basalts in the Raglan horizon, Cape Smith Belt, northern Quebec (Lesher 1999), suggesting that some of the mineralized komatiitic basalts there are post-lithification intrusions, not seafloor lavas.

The tops of komatiitic lavas are coherent or fractured, or consist of in situ quench-fragmented, jigsawfit to clast-rotated hyaloclastite breccia. There are also reports of ropy wrinkles on the surfaces of some 
A

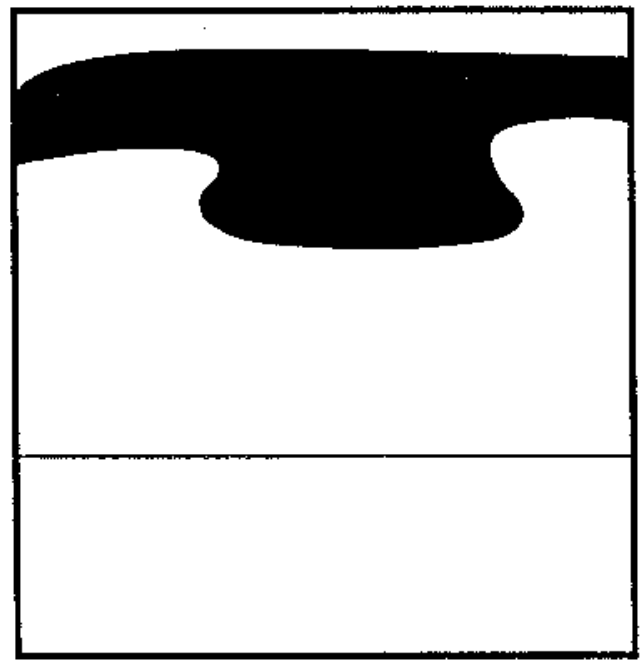

C

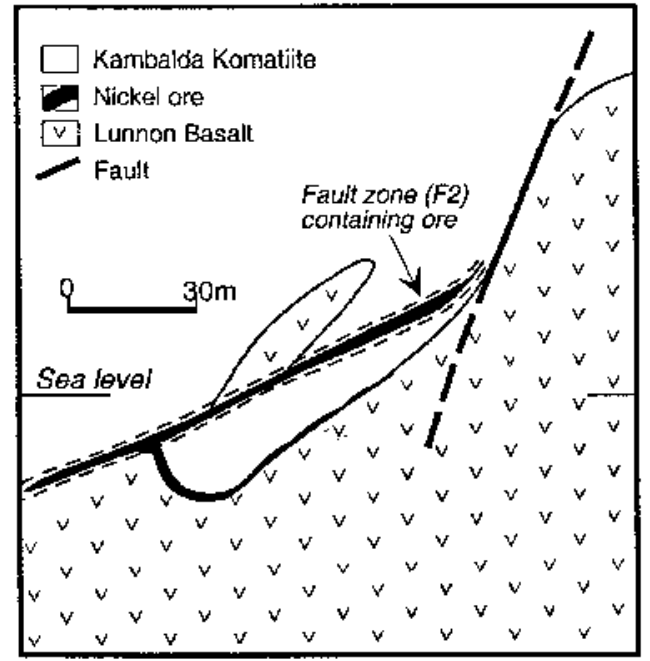

B

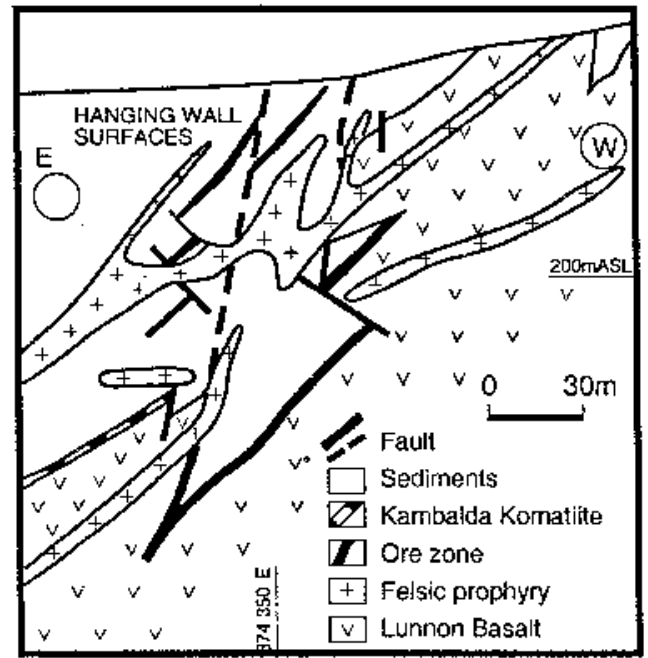

D

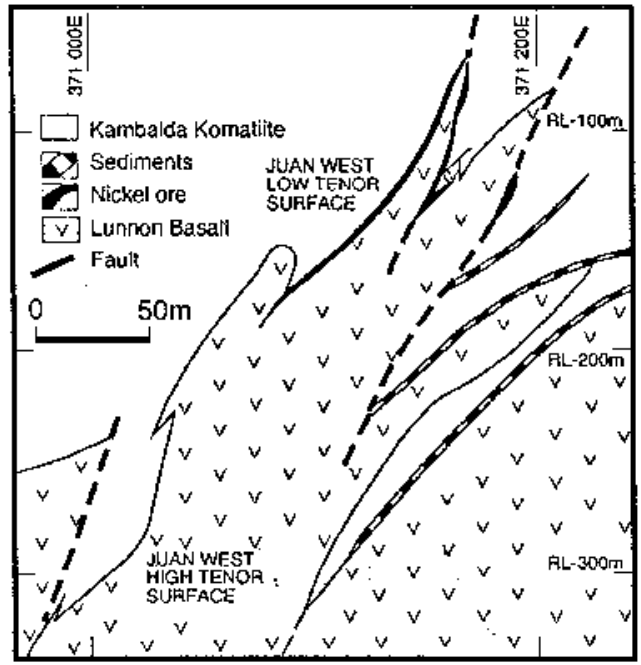

FIG. 5. (A) Experimental shape of thermal erosion channels using wax experiments (from Jarvis 1995). (B) Fault-bounded trough, Lunnon ore shoot, Kambalda, from Gresham \& Loftus-Hills (1981). (C) Fault-modified trough, Hunt deposit, Kambalda, from Cowden \& Roberts (1990). (D) Faulted Otter-Juan deposits, Kambalda, from Cowden \& Roberts (1990).

komatiitic basalts, similar to those characteristic of basaltic pahoehoe lavas (Wilson \& Versfeld 1994).

Hyaloclastite breccias at the margins of komatiites, grading into chaotic breccias of komatiite clasts in a structureless sediment, usually a pelitic or mudstone matrix, are also now known [e.g., Kambalda: Beresford \& Cas (2001); Dundonald Beach, Abitibi Belt: Davis (1999); Komati River, Barberton Belt and Raglan Belt, northern Quebec: personal observations; Fig. 7]. These breccias are peperites [see Cas \& Wright (1987) for dis- 


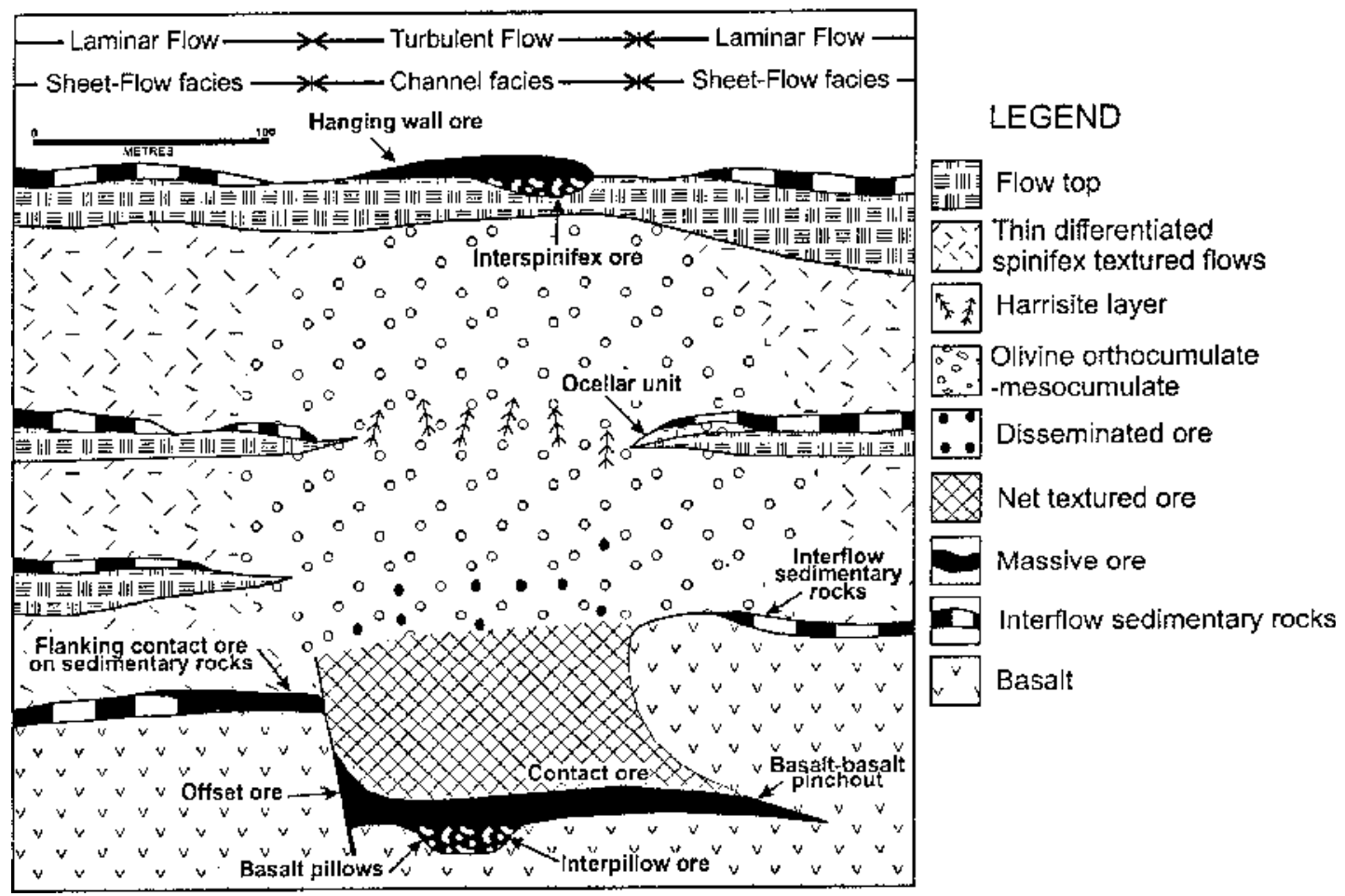

FIG. 6. Diagrammatic cross-section illustrating the location of sulfide bodies and the relation between channel facies and sheetflow facies of the Silver Lake Member of the Kambalda Komatiite. Note that the embayment or trough only partially confines the orebody and is largely a structural feature. Both figure and caption from Cowden \& Roberts (1990).

cussion of origins], resulting from the heating and fluidization of pore water in the sediments, and dynamic mixing of quench-fragmented hyaloclasts into the fluidized sedimentary matrix. Peperites can occur at the bases of both lava flows and syndepositional intrusions. However, where they occur at the top contact of a komatiite, they indicate that the komatiite resulted from syndepositional intrusion into soft, water-saturated, unconsolidated sediment.

\section{Turbulent Flow and Thermal Erosion}

Huppert \& Sparks (1985) considered that komatiitic magma flowed turbulently in near-vent settings because of anticipated high rates of magma discharge, resulting from low viscosity and high lithostatic pressure in the mantle source-region driving the komatiitic magma upward at a high velocity. However, many basalts are erupted under low to moderate rates of discharge and rarely flow turbulently. Low viscosity therefore does not necessarily lead to high rates of magma discharge, nor to turbulent flow.

Huppert \& Sparks (1985) calculated that at two-dimensional discharge rates of $0.5 \mathrm{~m}^{2} \mathrm{~s}^{-1}$, a $0.3-\mathrm{m}$-thick flow of komatiitic lava would advance at $2 \mathrm{~m} \mathrm{~s}^{-1}$ with a Reynolds Number $(\mathrm{Re})$ of $5 \times 10^{3}$. At a higher rate of discharge of $100 \mathrm{~m}^{2} \mathrm{~s}^{-1}$, flow velocity would be $10 \mathrm{~m} \mathrm{~s}^{-1}$, flow thickness, $10 \mathrm{~m}$, and $\mathrm{Re}, 10^{6}$. In both circumstances, flow conditions would be turbulent near the vent.

Conditions of turbulent flow were considered to be important to explain the existence of localized trough structures at the base of some komatiite flows at Kambalda. Huppert et al. (1984) suggested that the troughs originated as channels formed through the thermal erosion and assimilation of the substrate over which the flows moved, whereas Lesher et al. (1984) considered that they originated through the modification of original volcanic paleotopography by thermal erosion. At Kambalda, the substrate consists of pelitic sea-floor sediments and pillow basalts (Squire et al. 1998). Turbulence was considered to have maintained a constant flux of heat to the substrate, so enhancing the potential to melt it (Huppert \& Sparks 1985). However, during the current on-going eruption in Hawai'i, Kauahikaua et al. (1998) have shown that thermal erosion in lava tubes into the base of the lava flow field occurred under conditions of laminar flow ( $\mathrm{Re}$ in the range 16 to 64$)$. 

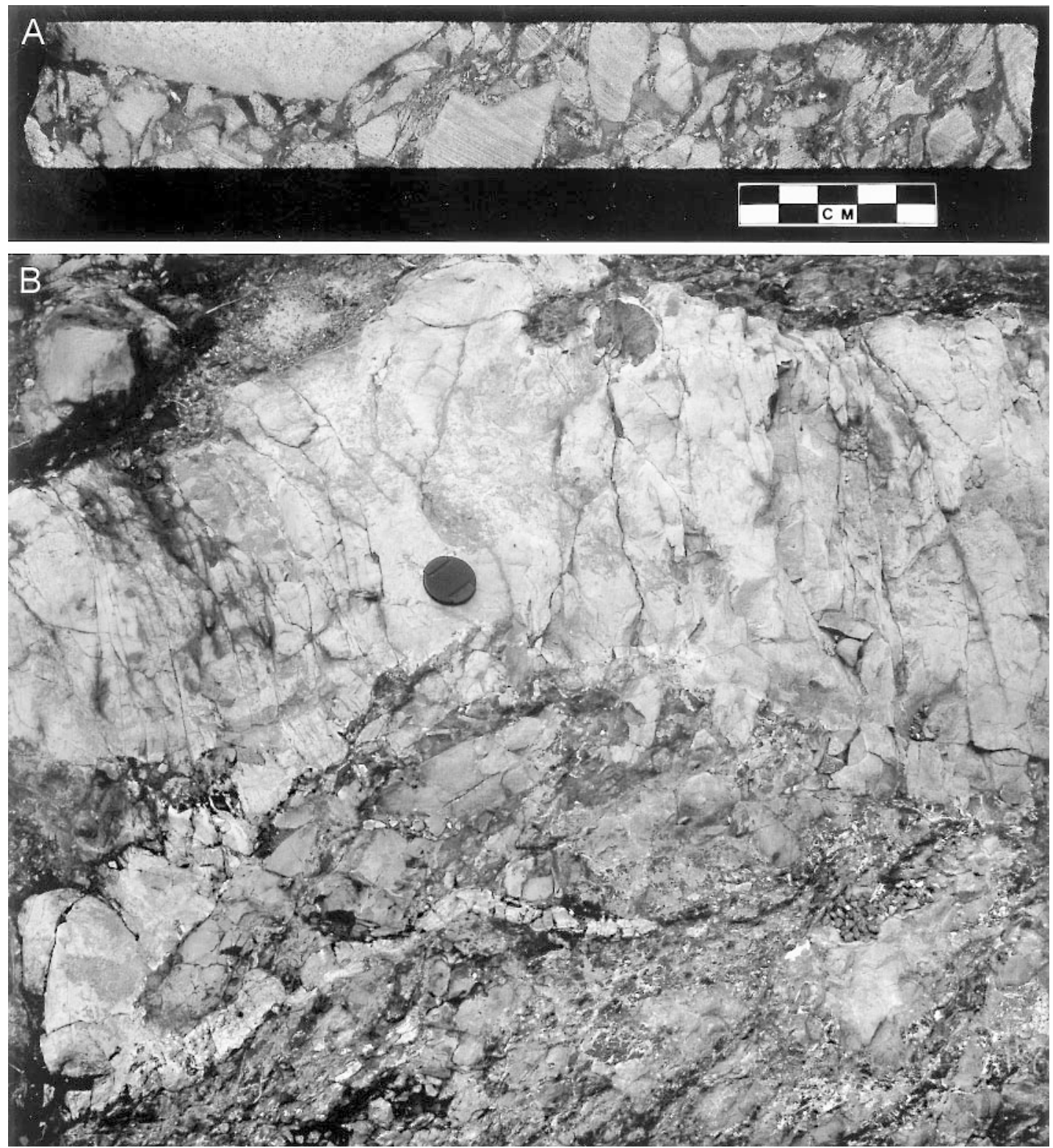

FIG. 7. (A) Komatiitic basalt peperite consisting of irregular, fluidal to blocky fragments of komatiite in a carbonaceous mudstone matrix. This grades downward into a coherent komatiite. Where such textures occur at the tops of igneous bodies, they can only represent intrusions into unconsolidated sediments, quench fragmentation of the margins, and convection-induced fluidization mixing of hyaloclasts from the margins of the intrusion into the fluidized sediment. From drill hole 718.904, Raglan horizon, Cape Smith Belt, northern Quebec. (B) Intrusive apophysis at the base of an intrusive and invasive komatiite lava lobe (both light color) intruding black shale, Dundonald Beach, Abitibi Belt, Ontario. The apophysis is intruding peperite consisting of grey komatiite clasts in a matrix of black shale. 
Turbulent flow therefore does not appear to be necessary for thermal erosion to occur. As noted above, the troughs are now fault-bounded structural features.

Thermal erosion is an important component of some ore-genesis models for komatiite-hosted nickel sulfide deposits because it provides a mechanism for adding sulfur to komatiitic magmas (Huppert \& Sparks 1985). Komatiitic magmas are considered to have been sulfurundersaturated; Huppert et al. (1984), Lesher et al. (1984), Lesher \& Groves (1986), Lesher (1989), and Hill et al. (1995) have suggested that melting and assimilation of sulfidic sediments on the seafloor, as magma flowed over them, would drive the magma to sulfur saturation, leading to precipitation of nickel sulfides.

The existence of troughs and the antithetic relationship between troughs and sediment have been the major lines of evidence used to support thermal erosion. However, as already stated, many troughs, if not all, appear to be structural features. In addition, sedimentary units can be thick under mineralized troughs (e.g., Blair mine: Marchiori 1995), and komatiites therefore did not always erode the sedimentary substrate in trough positions. In the areally more extensive flank positions, komatiites did not erode troughs or channels into substrate sediments, and many komatiites have completely planar, conformable bases everywhere, with no evidence at all of troughs anywhere.

Geochemical data have also been cited in support of thermal erosion. First, the need to explain how komatiitic magma became sulfur-saturated has virtually led to the assumption that melting and assimilation of sulfidic sediments on the seafloor did occur (e.g., Huppert et al. 1984). Such an approach is circumstantial and circular. Although some assimilation and contamination of sediment may have occurred, komatiitic magma could also have assimilated sulfur-bearing crustal rocks through which they passed before eruption, as proposed for the mineralized mafic intrusive host-rocks for the Noril'sk, Siberia (Lightfoot \& Hawkesworth 1997) and Voisey's Bay, Labrador (Naldrett 1997) orebodies, respectively.

Using $\mathrm{Nd}-\mathrm{Sm}$ isotopic and rare-earth-element (REE) geochemistry of mineralized and unmineralized komatiites at Kambalda, certain authors have suggested that some komatiites show evidence for sediment assimilation (Lesher \& Groves 1986, Arndt \& Jenner 1986). In contrast, others used Re-Os (Foster et al. 1996) and mass-balance calculations (Gresham 1986) to indicate that the evidence for contamination is ambiguous. Foster et al. (1996) proposed that post-emplacement alteration could produce misleading geochemical characteristics. Other komatiites apparently show no geochemical evidence of contamination (e.g., Arndt \& Jenner 1986, Lesher \& Arndt 1995). The significance of the geochemical data is therefore not always clear.

Greeley et al. (1998) evaluated the strength of the evidence for thermal erosion by mafic and ultramafic lavas worldwide, using criteria such as channel morphology, truncation of substrate layers, anatexis textures, xenoliths and xenomelts. They concluded that the evidence for thermal erosion is not strong. This must raise considerable doubt about how common the process is. The presence of ocelli, which are felsic clots interpreted as immiscible droplets (xenomelts) of assimilated sediment in komatiites, has been been cited as evidence for sediment assimilation (Frost \& Groves 1989), but these are not ubiquitous either. Xenoliths have rarely been recorded (e.g., Perring et al. 1995), but these could as easily have resulted from physical erosion, as discussed below.

In summary, the field evidence for thermal erosion is ambiguous, generally circumstantial, and the need to invoke conditions of turbulent flow to facilitate thermal erosion is not essential. Although heat-budget calculations (Huppert et al. 1984, Williams et al. 1998) indicate that komatiitic flows had the thermal capacity to melt their substrate, and some troughs may have been the product of this process, substrate melting was not ubiquitous (also see Groves et al. 1986), and most troughs now appear to be structural features.

\section{Capacity of Komatites for Physical Erosion}

If sediment is missing beneath some troughs and the evidence for thermal erosion is not strong, then sediment must have been removed by physical erosion. Although some authors have used the term "thermo-mechanical" erosion, referring to the thermal weakening and then physical shearing of clasts of substrate by komatiitic magma (e.g., Greeley et al. 1998), the processes of physical erosion by komatiitic flows are poorly understood, but have been initially considered by Squire et al. (1998). First, the high density-contrast between komatiites $\left(2.8 \mathrm{~g} \mathrm{~cm}^{-3}\right)$ and the water-saturated, unconsolidated sediments (density of 1.5-2.0 $\mathrm{g} \mathrm{cm}^{-3}$ ) over which they flowed, would have created a density inversion, causing many komatiitic lavas to scour and founder into the sediments (Fig. 8A). In some cases, komatiitic magma would have invaded the sediment by downward and lateral syndepositional intrusion (Beresford \& Cas 2001). This effect would be enhanced if the base of the komatiite flows were enriched in even denser sulfide liquid. Significant erosional scours or channels would be expected, and considerable volumes of sediment would be eroded and mobilized.

Secondly, if a komatiitic magma were turbulent, it would have had considerable capacity for physical erosion because of the turbulent eddies generated (Fig. 8B), like any other turbulent surface current. Thirdly, the flow front of a komatiitic lava, if it were travelling at high enough velocity, would have generated a turbulent bow wave in the water mass immediately ahead of the flow front (Fig. 8B). The very high heat budget of komatiites would also have produced significant physi- 


\section{A. Density induced scouring}

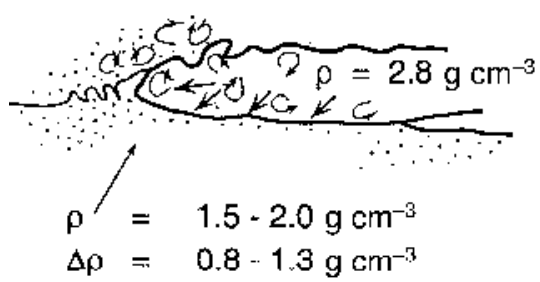

\section{B. Turbulent flow \& turbulent bow wave}

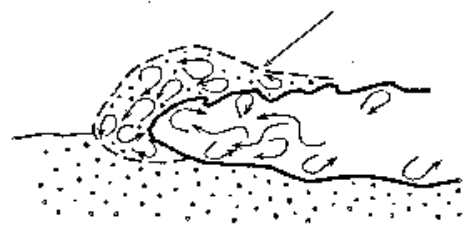

\section{Hjulstrom threshold erosional velocity - grainsize relationships, Stokes settling velocities (Law)}

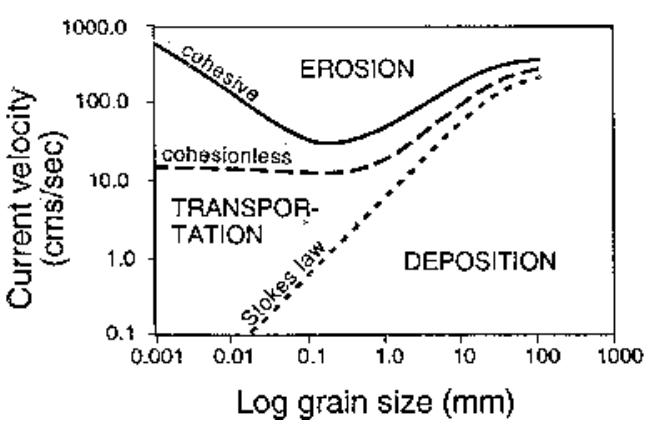

\section{Film boiling}

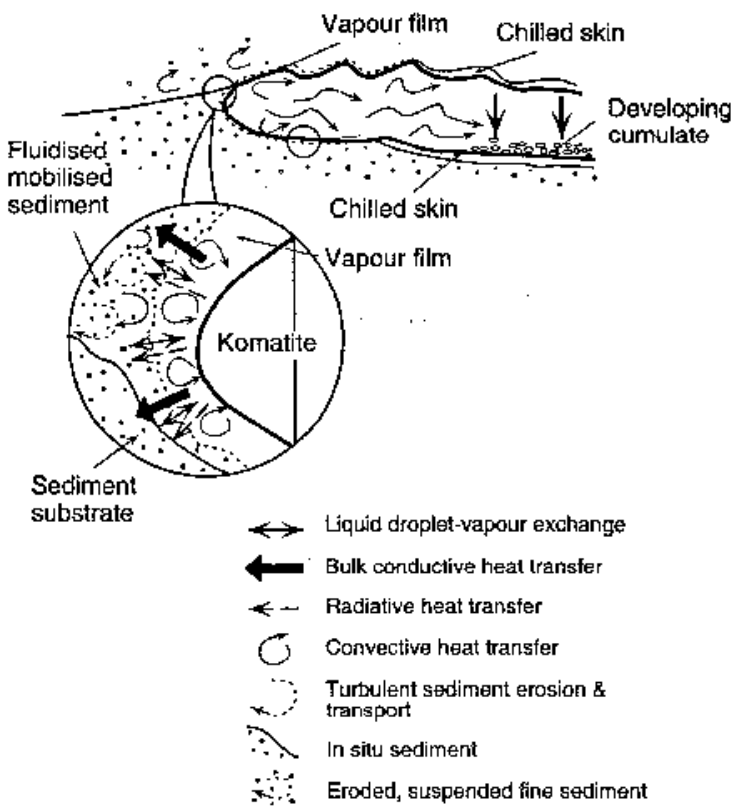

FIG. 8. (A) Scouring by dense and turbulent komatiitic lava into low-density, water-saturated, unconsolidated pelitic sediment due to density inversion and lava-flow turbulence. (B) Erosive turbulent bow wave of water and eroded sediment generated by the tubulent flow front of a komatiite lava. (C) Hjulstrom diagram depicting velocity - grain-size relationships, the fields for erosion, transportation and deposition, and an approximate representation of Stokes Law for grain settling velocities (lower dashed curve). (D) Film boiling at the interface between komatiite lava, the ambient water mass and the water-saturated sediment over which the lava is flowing. Film boiling of pore water in the sediment fluidizes the sediment, causing it to be mobilized, eroded and suspended.

cal erosion. When magma comes in contact with water, the water at the interface boils and flashes to steam in a process called film boiling (Mills 1984). Film boiling produces a turbulent, high-temperature, high-pressure film of vapor, perhaps only millimeters to centimeters thick (Fig. 8C). This film insulates and protects the lava from both explosive and quench fragmentation as long as it remains stable sufficiently long enough for a skin or crust to form on the surface of the lava, which may only be seconds to microseconds (Moore 1975, Mills 
1984). Heat transfer across the film of vapor to the adjacent mass of water occurs by bulk-layer conduction, convection, and radiation, and is accompanied by a significant temperature-gradient that induces convection in the water mass immediately around the margins of the vapor film (Fig. 8C). Turbulent, convective circulation at high velocities in both the water mass and the vapor film ahead of the advancing flows of komatiitic lava would therefore also contribute to the physical erosion of unconsolidated sediment.

In addition, the pore water in the sediments over which komatiitic lavas were propagating would also have been affected. Boiling and fluidization leading to convective mixing and liquefaction of the sedimentwater mixture should have occurred in some cases, given the high temperatures of komatiites. Mobilization and erosion of sediment ahead of, and under, the front of the advancing hot lava flow should thus have occurred (Fig. 8C). The mobilized sediment - water steam slurry would have been squirted ahead of the flow front and become suspended by turbulence as the flow propagated underneath. By fluidizing and liquifying the underlying sediment, a lava could stope an erosional channel in its path.

All of these physical erosional effects would be reduced if flows were laminar because stable boundarylayers would develop, enhancing cooling of the lava margins and formation of crusts at upper, lower and marginal surfaces. Lava would be less likely to scour into sedimentary substrate because of the restraining effect of the strength of the lower crust, the surrounding water would be less turbulent, and heat transfer to the water would be reduced by the insulating effect of the crust on heat loss.

Given that the sedimentary units in the Kambalda and nearby greenstone successions originated as pelitic and fine siliceous sediments (Bavinton 1981, Marchiori 1995, Squire et al. 1998), very low velocities and low levels of turbulence would be required to erode these. The minimum velocities required to erode unconsolidated clay- to silt-size sediments is only $5 \mathrm{~cm} \mathrm{~s}^{-1}$, or $100 \mathrm{~cm} \mathrm{~s}^{-1}$ for cohesive sediment using the Stokes settling velocities of silt- and clay-size particles, and data from Hjulstrom (Sundborg 1956; Fig. 8D), or Shields diagrams. This mobilized fine sediment would then remain suspended in the water mass until settling velocities dropped below the Stokes Law threshold velocities (Fig. 8D). Near-vent velocities calculated by Huppert et al. (1984) are considerably greater than these values, ranging from $180 \mathrm{~cm} \mathrm{~s}^{-1}$ for flows only $27 \mathrm{~cm}$ thick at two-dimensional discharge rates of $0.5 \mathrm{~m}^{2} \mathrm{~s}^{-1}$ to 1080 $\mathrm{cm} \mathrm{s}^{-1}$ for flows $926 \mathrm{~cm}$ thick at discharge rates of 100 $\mathrm{m}^{2} \mathrm{~s}^{-1}$. Although turbulence levels and induced velocities in the water mass marginal to the flowing komatiite would have been less, because of friction and shear at the magma-water interface, they are still likely to have been greater than the threshold velocities required for erosion. Significantly, these processes of physical ero- sion would have occurred instantaneously at the flow front before time-dependent thermal erosion could have commenced.

\section{Discussion}

Some of the principal characteristics of komatiites overviewed above can now be considered in terms of their significance for understanding the flow behavior of komatiitic lavas.

\section{Implications of coherent tops and bottoms: laminar flow and tube-fed lavas}

The characteristics of komatiites outlined provide important constraints on their flow behavior. The bases of most komatiites are conformable and non-erosional, indicating that the emplacement process of these highdensity, low-viscosity lavas was remarkably passive in most cases. Only where erosional channels occur along bases could flows have been turbulent. Given that such channels are localized to small areas at the base of some komatiites, only the initial parts of some flows could have been turbulent, and as the flow field enlarged, it settled into a more tranquil laminar-flow state (Cas et al. 1999). This state of tranquil flow is also suggested by the ubiquitous coherent to only locally quench-fragmented tops and margins of komatiites, represented by widespread intact, well-developed spinifex zones, and the surprising absence of autobreccias at the margins of komatiites. These characteristics are similar to the coherent to locally quench-fragmented margins of submarine pillow lavas. Pillow basalts are emplaced under relatively tranquil laminar-flow conditions. As the flow front propagates by the breakout of pillow lobes, the magma chills to form a glassy crust that then insulates the liquid interior of the flow. The crust remains stationary while lava beneath the skin continues to flow to the flow front, where it feeds new breakout lobes (Moore 1975, Cas \& Wright 1987).

In light of the field evidence of the intact spinifex zone, komatiites probably propagated in the same way. For some komatiitic flows, the breakouts were sheets, and for some, they were lobes. Large-volume sheet-like flood basalts are essentially sheet pahoehoe lavas that also have largely coherent, locally ropy-textured surface crusts. Originally, flood basalts were considered to have been highly turbulent, high-velocity flows to account for flow distances of up to $500 \mathrm{~km}$ (Shaw \& Swanson 1970, Swanson et al. 1975). It has now been calculated that turbulence would in fact cause too much heat loss to the atmosphere, making the flows too viscous to flow over the distances involved (Ho \& Cashman 1997, Keszthelyi $\&$ Self 1998). The same argument should apply to komatiites, especially in submarine environments, where heat loss to the aqueous medium would be greater than in air owing to the greater heat capacity and conductivity of water compared with air. 
Basalt lavas flow long distances through the development of interior lava tubes beneath surface crusts. The crusts insulate lava in the interior tubes from heat loss, and so magma can be transferred from the vent to the flow front with little loss of heat. This process is well documented from the on-going eruption in Hawai' $i$ (Hon et al. 1994, Kauahikaua et al. 1998), and similar mechanisms have been invoked for flood basalts (Self et al. 1996, 1997, Kesthelyi \& Self 1998, Thordarson \& Self 1998). The two textural zones of komatiites (spinifex A, cumulate B) can be logically interpreted as lavacrust and lava-tube facies, with the same tube-fed process of magma supply operating as in basalts. This is particularly the case for thick flows, which do not appear to have evidence for mass balance. Dynamic flow of magma and recharge through tubes are considered to lead to a realistic model. In this case, the spinifex crust represents the initial erupted composition of the magma. The Mg-enriched nature of the B zone results from continuous sedimentation of olivine from flow-through of magma in the tube under conditions of laminar flow.

Are mesoscopic lobes in komatiites the equivalent of pillows in pillow basalts?

Although "normal" basalt-like pillows are known from komatiitic basalts, they have not been reported in komatiites sensu stricto. Basalt pillows normally have an aspect ratio of 1:1 in cross section. The lobes described above from Spinifex Ridge appear to be indicative of a similar process of propagation in komatiites as occurs in pillow basalts and pahoehoe lavas, but they have lower aspect ratios and flatter, wider forms, called lobes here. The larger and flatter form of the komatiite lobes may be a reflection of the lower viscosity and of the higher temperature of the magma. The higher temperature may cause the visco-elastic crust that forms on a propagating breakout lobe or sheet to remain viscous longer and to stretch more before solidifying, compared with the case of basalts. Most importantly, if this analogy is correct, and outcrop-scale lobes in komatiites are the equivalent of pillow lobes in basalts, then it again suggests conditions favoring propagation by laminar flow.

\section{Preserved thicknesses and flow inflation}

Another outcome of the research into processes of lava-flow propagation in Hawai' $i$ is the realization that the thickness of basalt lavas progressively increases during the flow event by the process of endogenous inflation (Hon et al. 1994). When the flow front first advances, it does so as a thin breakout lobe or sheet from under the crust near the front of the lava. This breakout is usually only $20 \mathrm{~cm}$ thick, and immediately, within seconds, a crust forms on the surface. This surface crust usually remains stationary as more lava passes under- neath through the tube to the advancing flow-front. Within days to weeks, the surface of the lava progressively rises, as the flow thickens from within. The crust also progressively thickens, but apparently so does the basal layer, with the effect that the level at which the tube lies within the lava also progressively rises.

Limited accounts of thermal erosion by basalts can be found. Kauahikaua et al. (1998) have discussed the possible thermal erosion that occurs in some lava tubes. This thermal erosion has been identified by the drop in the level of the floor of the lava tube. If thermal erosion has occurred, it has occurred under laminar-flow conditions (Kauhaikaua et al.1998), and the thermally eroded material appears to have been only the immediately subjacent basalt emplaced during the current eruption, not pre-existing older basaltic substrate.

The preserved thickness of tens to hundreds of meters for some komatiites is anomalous, given the low viscosity of the magmas. Cas et al. (1999) have evaluated the flow-front thicknesses of komatiitic lavas at the time they were propagating, using the Jeffreys equation. They concluded that like basalts, and allowing for the significantly lower viscosity, most komatiites would have had flow fronts only a few centimeters to twenty centimeters thick. Only viscous (10 Pa s) flows would have had thicknesses of a few meters. It is unlikely that any flows had flow fronts tens of meters thick, and certainly not hundreds of meters thick. Cas et al. (1999) concluded that komatiites, like basalts, thickened by endogenous inflation, and that extremely thick komatiites, which are in places dunites, were almost certainly intrusions, or fault-stacked successions, or at best deeply ponded lava lakes.

There is also good evidence for inflation and a tubefed process in the field characteristics of komatiites, especially from a few key localities, such as Spinifex Ridge, La Motte Township, Quebec. As described above, both sheet or tube lobes and smaller lobes there have upward convex surfaces that sit above the level of the tapered margins of the lobes. This could only occur by inflation and up-arching of the aphyric and spinifextextured crust of the flow lobes. An open surface flow of komatiite, with the viscosity of olive oil, would simply fill in paleotopographic lows, and develop a flat surface lying at the same level as the lobe or sheet margins. The flow surface would not be up-arched.

In addition, the surface aphyric and spinifex crusts of the lobes are commonly fractured. The fractures are spaced from centimeters to tens of centimeters apart, they are perpendicular to the surfaces of the lobes, and they propagate irregularly downward into the spinifex zone. These fractures would normally be interpreted as in situ contraction cracks. They would have formed at the interface of the hot surface of the komatiitic lava with the ambient cold seawater, forming a chilled glassy crust as the magma was chilled through the range of the glass-transition temperature. The transition to solid glass involves considerable volume contraction, which is ac- 
commodated by the formation of spaced contraction cracks. Cracks with a similar morphology, however, would also develop if a visco-elastic to brittle crust were stretched or subject to extension by up-arching of the crust during inflation, as more magma is injected into the tube (Hon et al. 1994). Such inflation and crust expansion would be inevitable if sedimentation of cumulate crystals were occurring during tube flow, so progressively filling in the tube. If the rate of magma supply to the tube remained constant, the fluid pressure would increase as the volume of the liquid-filled part of the tube decreased owing to sedimentation of crystals at the base of tube. Increase of fluid pressure would cause up-arching and stretching of the crest of the tube.

\section{Flow evolution away from vent in time and space, and erosional processes}

In near-vent settings, komatiitic magmas would have been turbulent if fed by high-velocity discharge of magma from the vent (Huppert \& Sparks 1985). The various processes of physical and thermal erosion considered above would all have been dynamic contributors to the formation of erosional channels at the bases of komatiite lavas. Significantly, the physical processes of erosion would have resulted instantaneously from the flow head, and would have occurred before thermal erosion could have occurred. Thermal erosion also may have occurred, but only once established channels or lava tubes formed behind the flow head, since a sustained constant source of heat would be required to cause melting of substrate. We suggest that physical erosion, which has largely been ignored, is supported by similarly limited field evidence as with thermal erosion, but may be the more plausible process.

In medial to distal settings, Cas et al. (1999) have demonstrated that as komatiitic lavas spread away from the vent, the velocity at the flow front would have become significantly less than that in near-vent channels and tubes. Only initial flow pulses may have been narrow turbulent-flow systems, capable of some physical erosion producing local channels. Once flows spread and widened, velocities would have become low enough to induce laminar flow, so reducing their erosional capacity. This flow evolution explains why channels are localized, why in flanking environments the bases of komatiite lavas are conformable, and why komatiites have coherent spinifex-textured crusts. Where basal channels are absent, komatiitic lavas must have been completely laminar in their flow behavior at those points. Some komatiites would have flowed in laminar fashion throughout. Significantly, massive sulfide is commonly, but not invariably, found in channels, suggesting a possible relationship between initial pulses of turbulent flow and mineralization. However, exceptions do occur, and such a relationship needs to be investigated cautiously.
The surprising lack of hyaloclastite: effective film boiling

It is surprising how little hyaloclastite is associated with the surface crusts of komatiites, especially given the high contrast in temperature of at least $1400^{\circ} \mathrm{C}$ between komatiites and ambient cold seawater. This temperature difference would have set up very high temperature-gradients, and should have triggered extreme supercooling, chilling and quench-induced fragmentation. That hyaloclastites are relatively rare can only be explained by extremely efficient film boiling at the boundary between the lava and the seawater (Mills 1984). The film of steam produced insulates the lava and buffers the cooling gradient below that required to induce quench fragmentation. The relatively rare occurrences of hyaloclastite represent collapse of the film because of instabilities, leading to direct contact between lava and water, critical supercooling and quench fragmentation. Stable films are more likely to successfully insulate the red-hot part of the lava surface from quench fragmentation under tranquil laminar-flow conditions than under conditions of turbulent flow.

\section{Why the bases of komatiites are not commonly inva- sive}

Given the very high density of komatiitic lavas (2.8 $\mathrm{g} \mathrm{cm}^{-3}$ ), it is surprising that where komatiites overlie low-density, water-saturated sediments, their base is not more commonly erosive or invasive into the sediments (unconsolidated water-saturated density of 1.5-2.0 g $\mathrm{cm}^{-3}$ ). If komatiites were turbulent, such a density instability should commonly lead to widespread scouring, burrowing and syndepositional intrusion or invasion of the sediments, as discussed under physical erosion. That komatiites are not more commonly invasive probably also indicates that emplacement of the komatiites was gentle, probably under laminar-flow conditions.

However, even under laminar-flow conditions, a dense liquid should founder into a less dense, watersaturated sediment, especially if that sediment is pelitic. That this is also not more common indicates that the thickness of the sheet of spreading lava was probably very thin, so minimizing the weight of lava bearing down on sediment at any point. Secondly, it indicates that the base of the lava had enough strength to prevent it from foundering into the sediment. This indicates that a strong visco-elastic or solid crust must have formed by chilling as soon as the lava flowed over the sediments. Tranquil laminar flow is indicated, not disruptive turbulent flow.

\section{Conclusions}

1. The field characteristics of komatiite lavas, especially the very localized development of possible ero- 
sional channels, the ubiquitous development of coherent to locally quench-induced fragmented tops and bottoms, the passive, conformable contacts between komatiites and underlying sediments, and the lack of autobreccias, are consistent with emplacement under tranquil laminar-flow conditions, not turbulent conditions. Even where localized erosional channels exist, the tops of flows seem to have been coherent, indicating that perhaps only narrow initial pulses of flow were turbulent, but then as the flows evolved, widened and thickened, conditions of laminar flow developed.

2. The spinifex $A_{1}$ and $A_{2}$ zones appear to have represented a surface crust that insulated an interior tube, represented by the $\mathrm{A}_{3}$ blade spinifex and $\mathrm{B}$ cumulate zones.

3. Consideration of fluid dynamic properties of komatiitic magma indicates that the propagating flow fronts were centimeters to tens of centimeters thick, and that flows inflated to observed thicknesses. This inflation is supported by the convex upper surfaces of flow lobes where these are preserved in the field. It is also supported by considerations of the hydraulic head, involving calculations of the thickness of the flow fronts of komatiites at the time they were advancing, as discussed by Cas et al. (1999).

4. Mesoscopic lobes in low-viscosity komatiitic magma appear to be the equivalent of pillows in higherviscosity basaltic magma, and therefore imply similar conditions of tranquil propagation in a laminar state. Their lower aspect-ratio (flatter profile) appears to be due to the lower viscosity of komatiitic magma.

5. The term structural trough should be used for fault-bounded depressions in the base of komatiites, and these should be distinguished from erosionally formed volcanic channels, for which clear field evidence must be documented.

\section{ACKNOWLEDGEMENTS}

We acknowledge the financial and logistical support provided by WMC Resources Limited and the financial support of an Australian Research Council Strategic Partnership with Industry - Research and Training (SPIRT) grant. In particular, we thank Dr. W. Stone, research geologist with WMC, Mr. Craig Redell, former chief geologist at Kambalda, and Mr. Jim Reeve, former chief geologist for nickel with WMC, for helping to establish our research project with WMC. We also thank Mr. Peter Bewick, chief geologist at Kambalda, for continuing support for this project and for permission to publish this paper, and also the geological staff at Kambalda for their interest in the results. We thank Steve Self for discussions on lava-flow dynamics and Yann Lahaye for reviewing this manuscript. We also thank Jim Kauahikaua, Sarah-Jane Barnes and an anonymous reviewer for helpful comments.

\section{REFERENCES}

ARCHIBALD, N.J. (1985): The stratigraphy and tectonic-metamorphic history of the Kambalda-Tramways area, Western Australia. Unpubl. WMC Rep. K/2889.

ARnDT, N.T. (1982): Proterozoic spinifex-textured basalts of Gilmour Island, Hudson Bay. Geol. Surv. Can., Pap. 821A, 137-142.

(1986): Differentiation of komatiite flows. J. Petrol. 27, 279-301.

Ginibre, C., Chauvel, C., Albarède, F., Cheadle, M., Herzberg, C., Jenner, G. \& Lahaye, Y. (1998): Were komatiites wet? Geology 26, 739-742.

\& JENNER, G.A. (1986): Crustally contaminated komatiites and basalts from Kambalda, Western Australia. Chem. Geol. 56, 229-255.

NaldRetT, A.J. \& Pyke, D.R. (1977): Komatiitic and iron-rich tholeiitic lavas of Munro Township, northeast Ontario. J. Petrol. 18, 319-369.

\& Nisbet, E.G., eds. (1982): Komatiites. George Allen \& Unwin, London, U.K.

BARAgAR, W.R.A. (1984): Pillow formation and layered flows in the Circum-Superior Belt of eastern Hudson Bay. Can. J. Earth. Sci. 21, 781-792.

BARNES, S.-J. (1985): The petrography and geochemistry of komatiite flows from the Abitibi Greenstone Belt and a model for their formation. Lithos 18, 241-270.

Barnes, S.J., Gole, M.J., \& Hill, R.E.T. (1983): The Agnew nickel deposit, Western Australia. II. Sulfide geochemistry, with emphasis on the platinum group elements. Econ. Geol. 83, 537-550.

BAVINTON, O.A. (1981): The nature of sulfidic metasediments at Kambalda and their broad relationships with associated ultramafic rocks and nickel ores. Econ. Geol. 76, 16061628 .

Beresford, S.W. \& CAS, R.A.F. (2001): Komatiitic invasive lava flows, Kambalda, Western Australia. Can. Mineral. 39, 525-535.

, LAMBERT, D.D. \& STONE, W.E. (2000): Vesicles in thick komatiite lava flows, Kambalda, Western Australia. J. Geol. Soc. London 157, 11-14.

Brown, M.A.N., Jolly, R.J.H., Stone, W.E. \& Coward, M. (1999): Nickel ore troughs in Archaean volcanic rocks, Kambalda, Western Australia; indicators of early extension. Geol. Soc., Spec. Publ. 155, 197-211.

Cas, R., Self, S. \& Beresford, S. (1999): The behaviour of the fronts of komatiite lavas in medial to distal settings. Earth Planet. Sci. Lett. 172, 127-139. 
\& Wright, J.V. (1987): Volcanic Successions: Modern and Ancient. Allen \& Unwin, London, U.K.

Claoue-Long, J.C., Compston, W. \& Cowden, A. (1988): The age of the Kambalda greenstones resolved by ion-microprobe: implications for Archean dating methods. Earth Planet. Sci. Lett. 89, 239-259.

Cowden, A. (1988): Emplacement of komatiite lava flows and associated nickel sulfides at Kambalda, Western Australia. Econ. Geol. 83, 436-442.

\& ARCHIBALD, N.J. (1991): Massive sulfide fabrics at Kambalda: sensitive records of deformation records. In Structural Geology in Mining and Exploration. Univ. Western Aust., Geol. Dep. \& Univ. Extension, Publ. 25, 99-102 (abstr.)

\& RoBERTS, D.E. (1990): Komatiite hosted nickel sulfide deposits, Kambalda. In Geology of the Mineral Deposits of Australia and Papua New Guinea (F.E. Hughes, ed.). The Australasian Institute of Mining and Metallurgy, Melbourne, Australia (567-581).

Dann, J., Wilson, A.H., \& Cloete, M. (1998): Magmatic diversity: volcanoes and their roots. In Komatiites in the Barberton and Nondweni Greenstone Belts. International Association of Volcanology and Chemistry of the Earth's Interior (IAVCEI) Congress (Cape Town), Field Excursion C1.

DAvis, P.C. (1999): Classic komatiite localities and magmatic $\mathrm{Fe}-\mathrm{Ni}-\mathrm{Cu}-(\mathrm{PGE})$ sulphide deposits of the Abititbi Greenstone Belt, Ontario-Quebec. Mineral Exploration Research Centre, Laurentian University, Sudbury, Ontario, Guidebook Ser. 1

Donaldson, C.H. (1982): Spinifex-textured komatiites: a review of textures, compositions and layering. In Komatiites (N.T. Arndt \& E.G. Nisbet, eds.). George Allen and Unwin, London, U.K. (213-244)

Evans, D.M., Cowden, A. \& Barratt, R.M. (1988): Deformation and thermal erosion at the Foster nickel deposit, Kambalda - St Ives, Western Australia. In Magmatic Sulfides: the Zimbabwe Volume (M.S. Prendergast \& M.J. Jones, eds.). Institution of Mining and Metallurgy, London, U.K. (215-219).

Foster, J.G., LAMBERT, D.D., FRICK, L.R. \& MAAS, R. (1996): $\mathrm{Re}-\mathrm{Os}$ isotopic evidence for genesis of Archaean nickel ores from uncontaminated komatiites. Nature 382, 703706

Frost, K.M. \& Groves, D.I. (1989): Ocellar units at Kambalda: evidence for sediment assimilation by komatiite lavas. In Magmatic Sulfides: the Zimbabwe Volume (M.D. Prendergast \& M.J. Jones, eds.). Institute of Mining and Metallurgy, London, U.K. (207-214).

Greeley, R., Fagents, S.A., Harris, R.S., Kadel, S.D., Williams, D.A. \& GUEST, J.E. (1998): Erosion by flowing lava: field evidence. J. Geophys. Res. 103, 27,325-27,345.
GreshaM, J.J. (1986): Depositional environments of volcanic peridotite-associated nickel sulfide deposits with special reference to the Kambalda Dome. In Geology and Metallogeny of Copper Deposits (G.H. Friedrich, A,D. Genkin, A.J. Naldrett, J.D. Ridge, R.H. Sillitoe \& F.M. Vokes, eds.). Springer-Verlag, Berlin, Germany (63-90).

\& Loftus-HiLls, G.D. (1981): The geology of the Kambalda nickel field, Western Australia. Econ. Geol. 76, $1373-1416$

Groves, D.I., Korkiakoski, E.A., McNaughton, N.J., LESHER, C.M. \& COWDEN, A. (1986): Thermal erosion by komatiites at Kambalda, Western Australia and the genesis of nickel ores. Nature 319, 136-139.

Hill, R.E.T., Barnes, S.J., Gole, M.J. \& Dowling, S.E. (1995): The volcanology of komatiites as deduced from field relationships in the Norseman-Wiluna greenstone belt, Western Australia. Lithos 34, 159-188.

Ho, A.M. \& CASHMan, K.V. (1997): Temperature constraints on the Ginkgo flow of the Columbia River Basalt Group. Geology 25, 403-406.

Hon, K., Kauahikaua, J., Denlinger, R. \& Mackay, K. (1994): Emplacement and inflation of pahoehoe sheet flows: observations and measurements of active lava flows on Kilauea Volcano, Hawaii. Geol. Soc. Am., Bull. 106, 351-370.

HupPERT, H. E. \& Sparks, R.S.J. (1985): Komatiites. I. Eruption and flow. J. Petrol. 26, 694-725.

TURNER, J.S. \& ARNDT, N.T. (1984): Emplacement and cooling of komatiite lavas. Nature 309, $19-22$.

JACKSON, S.L. \& FYON, J.A. (1991): The Western Abitibi subprovince in Ontario. In Geology of Ontario (P.C. Thurston, H.R. Williams, R.H. Sutcliffe \& G.M. Stott, eds.). Ontario Geol. Surv., Spec. Vol. 4(1), 405-482.

JARVIS, R.A. (1995): On the cross-sectional geometry of thermal erosion channels formed by turbulent lava flows. $J$. Geophys. Res. 100, 10,127-10,140.

Kauahikaua, J., Cashman, K.V., Mattox, T.N., Heliker, C.C., Hon, K.A., Mangan, M.T. \& Thornber, C.R. (1998): Observations on basaltic lava streams in tubes from Kilauea Volcano, island of Hawai'i. J. Geophys. Res. 103, 27,303-27,323.

KeszThelyi, L. \& Self, S. (1998): Some physical requirements for the emplacement of long basaltic lava flows. $J$. Geophys. Res. 103, 27,447-27,464.

LAJOIE, J. \& GÉLINAS, L. (1978): Emplacement of Archean peridotitic komatiites in La Motte Township, Quebec. Can. J. Earth. Sci. 15, 672-677.

LESHER, C.M. (1983): Localisation and Genesis of KomatiiteAssociated $\mathrm{Fe}-\mathrm{Ni}-\mathrm{Cu}$ Sulfide Mineralization at Kambalda. Ph.D. thesis, Univ. Western Australia, Perth, Australia. 
(1989): Komatiite associated nickel sulfide deposits. In Ore Deposition Associated with Magmas (J.A. Whitney \& A.J. Naldrett, eds.). Rev. Econ. Geol. 4, 45-101.

ed. (1999): Komatiitic periotite-hosted Ni-Cu(PGE) deposits of the Raglan area, Cape Smith Belt, New Québec. Mineral Exploration Research Centre, Laurentian University, Sudbury, Ontario, Guidebook Ser. 2.

\& ARnDT, N.T. (1995): REE and Nd isotope geochemistry, petrogenesis and volcanic evolution of contaminated komatiites at Kambalda, Western Australia. Lithos 34, 127-157.

\& Groves, D.I. (1984): Genesis of komatiite-associated nickel sulfide deposits at Kambalda, Western Australia: a distal volcanic model. In Sulfide Deposits in Mafic and Ultramafic Rocks (D.L. Buchanan \& M.J. Jones, eds.). The Institute of Mining and Metallurgy, London, U.K. (70-80).

\& GRoves, D.I. (1986): Controls on the formation of komatiite-associated nickel-copper sulfide deposits. In Geology and Metallogeny of Copper Deposits (G.H. Friedrich, A.D. Genkin, A.J. Naldrett, J.D. Ridge, R.H. Sillitoe \& F.M. Vokes, eds.). Springer-Verlag, Berlin, Germany (43-62).

Lightfoot, P.C. \& HAwKesworth, C.J. (1997): Flood basalts and magmatic $\mathrm{Ni}, \mathrm{Cu}$, and PGE sulfide mineralization: comparative geochemistry of the Noril'sk (Siberian Traps) and West Greenland Sequences. In Large Igneous Provinces: Continental, Oceanic, and Planetary Flood Volcanism (J.J. Mahoney \& M.P. Coffin, eds.). Am. Geophys. Union, Monogr. 100, 357-380.

MARCHIORI, K. (1995): The Stratigraphy of the Blair Mine, with Special Reference to the Sedimentary Rocks. B.Sc. (Hons) thesis, Monash Univ., Clayton, Australia.

Mills, A.A. (1984): Pillow lavas and the Leidenfrost effect. $J$. Geol. Soc. London 141, 183-186.

Moore, A.G. (1998): A Volcanic Facies Model for the McComish Prospect, Tramways, Kambalda, W.A. B.Sc. (Hons.) thesis, Monash Univ., Clayton, Australia.

, CAS, R.A.F., BERESFORD, S.W. \& STONE, M. (2000): Geology of an Archaean metakomatiite succession, Tramways, Kambalda Ni province, W.A.: assessing the extent to which volcanic facies architecture and flow emplacement mechanisms can be reconstructed. Aust. J. Earth. Sci. 47, 659-673.

Moore, J.G. (1975): Mechanism of formation of pillow lava. Am. J. Sci. 263, 269-277.

NALDRETT, A.J. (1997): Key factors in the genesis of Noril'sk, Sudbury, Jinchuan, Voisey's Bay and other world class Ni$\mathrm{Cu}-\mathrm{PGE}$ deposits: implications for exploration. Aust. J. Earth Sci. 44, 283-315.

NisBet, E.G. (1982): The tectonic setting and petrogenesis of komatiites. In Komatiites (N.T. Arndt \& E.G. Nisbet, eds.). George Allen \& Unwin, London, U.K. (501-520).
Perring, C.S., Barnes, S.J. \& Hill, R.E.T. (1995): The physical volcanology of Archean komatiite sequences from Forrestania, Southern Cross Province, Western Australia. Lithos 34, 189-207.

Pyke, D.R., Naldrett, A.J. \& Eckstrand, O.R. (1973): Archean ultramafic flows in Munro Township, Ontario. Geol. Soc. Am., Bull. 84, 955-978.

Ross, J.R. \& HoPkins, G.M.F. (1975): Kambalda nickel sulphide deposits. In Economic Geology of Australia and Papua New Guinea. 1. Metals (C.L. Knight, ed.). The Australasian Institute of Mining and Metallurgy, Melbourne, Australia (100-121).

Self, S., Thordarson, T.H. \& Keszthelyi, L. (1997): Emplacement of continental flood basalt lava flows. In Large Igneous Provinces: Continental, Oceanic, and Planetary Flood Volcanism (J.J. Mahoney \& M. Coffin, eds.). Am. Geophys. Union, Monogr. 100, 381-410.

WALKER, G.P.L., HoN, K., Murphy, M.T.,LONG, P. \& FinNEMORE, S. (1996): A new model for the emplacement of Columbia River basalts as large, inflated pahoehoe lava flow fields. Geophys. Res. Lett. 23, 2689-2692.

SHAw, H.R. \& SWANSON, D.A. (1970): Eruption and flow rates of flood basalts. In Second Columbia River Basalt Symposium (E.H. Gilmour \& D. Stradling, eds.). Eastern Washington State College University Press, Cheney, Washington (271-299).

Shore, M. \& Fowler, A.D. (1999): The origin of spinifex texture in komatiites. Nature 397, 691-694.

SQuire, R.J., CAs, R.A.F., Clout, J.M.F. \& BeHETs, R. (1998): Volcanology of the Archaean Lunnon Basalt and its relevance to nickel sulfide-bearing trough structures at Kambalda, Western Australia. Aust. J. Earth Sci. 45, 695715 .

ST-ONGE, M.R. \& LuCAS, S.B. (1994): Controls on the regional distribution of iron - nickel - copper - platinum-group element sulfide mineralization in the eastern Cape Smith Belt, Quebec. Can. J. Earth Sci. 31, 206-218.

SundBorg, A. (1956): The River Klaralven, a study of fluvial processes. Geografiska Annal., Ser. A 38, 125-316.

Swanson, D.A., Wright, T.L. \& Helz, R.T. (1975): Linear vent systems and estimated rates of magma production and eruption for the Yakima basalt on the Columbia Plateau. Am. J. Sci. 275, 877-905.

Thordarson, T.H. \& SElf, S. (1998): The Roza member, Columbia River Basalt Group: a gigantic pahoehoe lava flow field formed by endogenous processes. J. Geophys. Res. $\mathbf{1 0 3}, 27,411-27,445$.

Williams, D.A., KerR, R.C. \& Lesher, C.M. (1998): Emplacement and erosion by Archean komatiite lava flows at Kambalda: revisited. J. Geophys. Res. 103, 27,533-27,549. 
$\&$

(1999): Thermal and fluid

dynamics of komatiitic lavas associated with magmatic Ni$\mathrm{Cu}$-(PGE) sulphide deposits. In Advances in Genetic Models and Exploration Strategies for Magmatic Sulphide Deposits (R.R. Keays, C.M. Lesher, P.C. Lightfoot \& C.E.G. Farrow, eds.). Geol. Assoc. Can., Short Course Notes 13.

Wilson, A.H. \& Versfeld, J.A. (1994): The early Archaean Nondweni greenstone belt, southern Kaapvaal Craton, South Africa. II. Characteristics of the volcanic rocks and constraints on magma genesis. Precamb. Res. 67, 277-320.
Wolfe, N.J. (1997): Volcanic Environments of the West Widgiemooltha Dome, Kambalda, Western Australia. B.Sc. (Hons.) thesis, Monash Univ., Clayton, Australia.

Received September 23, 1999, revised manuscript accepted September 10, 2000. 